\title{
Evaluation of Growth Performance, Haematological and Serum Biochemical Response of Broiler Chickens to Aqueous Extract of Ginger and Garlic
}

\author{
Vivian U. Oleforuh-Okoleh ${ }^{1,2}$, Harriet M. Ndofor-Foleng ${ }^{3}$, Solomon O. Olorunleke ${ }^{1} \&$ Joesph O. Uguru $^{1}$ \\ ${ }^{1}$ Department of Animal Science, Ebonyi State University, Abakaliki, Ebonyi State, Nigeria \\ ${ }^{2}$ Department of Animal Science, Rivers State University of Science and Technology, Nkpolu-Oroworukwo, Port \\ Harcourt, Rivers State, Nigeria \\ ${ }^{3}$ Department of Animal Science, University of Nigeria, Nsukka, Enugu State, Nigeria \\ Correspondence: Vivian U. Oleforuh-Okoleh, Department of Animal Science, Rivers State University of Science \\ and Technology, Nkpolu-Oroworukwo, PMB 5080, Port Harcourt, Rivers State, Nigeria. Tel: 234-803-607-2087. \\ E-mail: vivoleh@gmail.com
}

Received: January 15, 2015 Accepted: February 27, 2015 Online Published: March 15, 2015

doi:10.5539/jas.v7n4p167 URL: http://dx.doi.org/10.5539/jas.v7n4p167

\begin{abstract}
An experiment which lasted for 56 days was carried out to investigate the growth performance, haematological and serum biochemical response of broiler chickens to aqueous extract of ginger and garlic. Eighty day-old Marshal Strain broiler chickens were used for the experiment. The birds were randomly allotted into four treatment groups consisting of four replicates with five birds per replicate. The aqueous extract was obtained by infusing $14 \mathrm{~g}$ of each test ingredient in 1 litre of hot boiled water for 12 hours and $50 \mathrm{ml}$ of the filtrate/litre of drinking water given to birds' ad-libitum. T1 (control), T2, T3, and T4 contained 0, and 50 mls of ginger, garlic and a 1:1 ratio mixture of ginger and garlic in drinking water respectively. T2 gave the best performance $(\mathrm{p}<$ 0.05 ) in all growth performance traits - final body weight, weekly weight gain, weekly feed intake and feed conversion ratio and T1 the least. Significant $(\mathrm{p}<0.01)$ increases were observed in haemoglobin concentration, packed cell volume, white blood cell, and red blood cell of the ginger and garlic treated birds. The serum biochemical parameters measured were significantly $(\mathrm{p}<0.05)$ different, with T2 and T3 showing a better response. Cholesterol decreased significantly $(\mathrm{p}>0.05)$ while there was significant increase in the total protein, albumin, and globulin of the treated birds $(\mathrm{p}<0.01)$. Administration of ginger and garlic to broiler chickens increased their performance, boosted their immunity as well as improved their general well-being. It is, thus, recommended in broiler chicken production.
\end{abstract}

Keywords: aqueous extract, body weight, chicken, cholesterol, feed intake, haematology, total protein

\section{Introduction}

In Nigeria, the effect of inadequate animal protein intake is felt more by a large proportion of the population especially in the rural areas. Poultry meat is a good source of animal protein and can contribute immensely in boosting the consumption level of animal protein. The prohibitive increase in the cost of input especially that of feed is among the constraints in commercial broiler production (Madubuike \& Ekenyem, 2001). Ensuring more net return and minimizing high expenditure for feed are the main challenges, for which many research strategies have been trying to address through the inclusion of feed supplements and feed additives in the diets of broiler chicken.

A major feed additive that has been extensively used is antibiotics. Antibiotics use in livestock is the use of antibiotics for any purpose in the husbandry of livestock, which include not only the treatment or prophylaxis of infection but also the use of sub-therapeutic doses in animal feed to promote growth and improve feed efficiency in contemporary intensive animal farming (Ogle, 2013). Incidentally, their use in animal feed has shown several side effects such as resistance towards the drug and evidence of resistant strains that become zoonotic (Wegener et al., 1999). The emergence of antibiotic resistance by pathogenic bacteria has led to international restriction on the use of antibiotics in animal feeds. Consequently, the poultry industry is under great pressure to minimize their use in animal feed and seek alternatives. These alternatives can be found in the use of herbs and spices 
materials as supplements. According to Manesh et al. (2012) natural alternatives to antibiotics, such as herbs and medicinal plants, have attracted attention due to their wide range of potential beneficial effects.

Natural medicinal products originating from herbs and spices have been used as feed additives for farm animals (Guo, 2003). The efficacy and importance of a particular feedstuff/feed ingredient in poultry production is evaluated from its effect on the production performance/traits of the birds. Furthermore, valuable information can be obtained from the study of the haematological parameters. This stems from the fact that the blood serves as an important index of physiological, pathological and nutritional status of an animal. Information obtained from haematological assay, apart from being useful for diagnostic and management purposes could equally be incorporated into breeding programmes (Elagib \& Ahmed, 2011). Two herbal plants which are nutritionally adequate and locally available in Nigeria that can be harnessed as feed additives are ginger (Ademola et al., 2009) and garlic (Gbenga et al., 2009). Ginger is a rhizomatous herbaceous plant, whose rhizome is used medicinally. Ginger contains several compounds and enzymes including gingerdiol, gingerol, gingerdione and shogaols (Rivlin, 2001; Zhao et al., 2011). These compounds have been reported to have antimicrobial, antioxidative and pharmacological effects (Al-Amin et al., 2006; Tapsell et al., 2006; Ali et al, 2008). Garlic is best known as a spice and herbal medicine for treatment and prevention of an array of diseases (Adibmoradi et al., 2006). The key active ingredient in garlic is a powerful plant chemical called allicin which rapidly decomposes to several organosulphur compounds with bioactivities (Chang \& Cheong, 2008). Several reports are available advocating the roles of these herbs in improving growth performance, meat quality, anti-cholesteremic effects and as well as immuno-modulating effects on broiler chickens (Gardzielewska et al., 2003; Aji et al., 2011; Ashayerizadeh et al., 2009; Hanieh et al., 2010; Ayasan, 2011).

The present study was carried out to evaluate the growth performance, haematological and serum biochemical indices of broiler chicks fed ginger and garlic aqueous extract.

\section{Materials and Methods}

\subsection{Study Location}

The present study was carried out at the Poultry Unit of the Teaching, and Research Farm of the Department of Animal Science, Ebonyi State University Abakaliki. Abakaliki is located within the south eastern guinea savannah ecological zone between latitude $8^{\circ} 30^{\prime}$ and $9^{\circ} 40^{\prime}$ North and longitude $5^{\circ} 40^{\prime}$ and $6^{\circ} 45^{\prime}$ East (Nwakpu, 2005). The experiment lasted for 49 days.

\subsection{Test Ingredients}

The fresh ginger and garlic used were purchased from Abakaliki market. The garlic and ginger were peeled, cut into chips and sundried for a period of six weeks. The dried garlic and ginger chips were ground into smooth powder and stored separately in an air tight container. Each aqueous extract was prepared by adding one liter of boiled hot water to $14 \mathrm{~g}$ of either ground ginger or garlic or a mixture of the two (at $7 \mathrm{~g}$ each) in separate non-metallic containers. The mixtures were allowed to infuse and cool at room temperature overnight for twelve hours. The next morning, the extract was obtained by filtering the infusion using a filter paper, and then administered to the chicks in their drinking water at $50 \mathrm{ml} /$ liter of water. The aqueous extract was made available to the birds for ad libitum. Fresh infusion was prepared daily. The procedure used for preparing the aqueous extract is in line with Leila (1977).

\subsection{Experimental Animals and Treatments}

A total of eighty day-old Marshal broiler chicks used for the study were purchased from Obasanjo Farms Nigeria Limited, Ota in Ogun State. The chicks were kept for seven days to acclimatize; within this period, they were fed commercial broiler starter diet only and given plain drinking water. On the $8^{\text {th }}$ day, the 80 chicks, having an average body weight of $121.66 \pm 5.00 \mathrm{~g}$ were randomly allotted to four experimental treatments in a completely randomly design (CRD). Each treatment was replicated four times with 5 chicks per replicate. The birds were housed in a wooden three-tier battery cage, each replicate cell measuring $30 \times 44 \times 21$ inches.

Four experimental treatments identified as $\mathrm{T}_{1}, \mathrm{~T}_{2}, \mathrm{~T}_{3}$, and $\mathrm{T}_{4}$ were studied. Birds on $\mathrm{T}_{1}$ (control treatment) received basal diet (commercial starter diet $-22 \% \mathrm{CP}, 2900 \mathrm{kcal} / \mathrm{kg}$ ME- fed for the first 28 days and finisher diet fed from the 28 to 49 day ( $18 \% \mathrm{CP}, 2900 \mathrm{kca} / \mathrm{kg} \mathrm{ME})$, and water without ginger or garlic. Those on $\mathrm{T}_{2}$ received the basal diet and were given ginger extract at $50 \mathrm{ml} /$ litre of water; birds on $\mathrm{T}_{3}$ received the basal diet and were given garlic extract at $50 \mathrm{ml} /$ litre of water, and those $\mathrm{T}_{4}$ were fed the basal diet and received extract of both ginger and garlic at $25 \mathrm{ml}$ each/litre of water. Proper management, necessary vaccinations and good environmental condition were maintained throughout the period of study. 


\subsection{Data Collection}

\subsubsection{Growth Performance}

Data were collected on growth performance traits (such as daily feed intake, weekly body weight, final body weight and feed conversion ratio).

\subsubsection{Haematological and Serum Biochemical Assay}

On the $56^{\text {th }}$ day of study, blood samples were randomly collected from four birds/treatment. The blood samples were collected via the wing veins using sterile needles and syringes. The blood samples for haematological parameters were collected into well-labeled and sterilized bottles containing ethylene diamine tetra acetic acid (EDTA), as anti-coagulant. The samples were investigated for the following haematological parameters - packed cell volume (PCV), red blood cell count (RBC), white blood cell (WBC), haemoglobin and platelets (Lamb, 1991). Blood samples for biochemical indices were collected into another sample bottles without the anticoagulant. Plasma samples were analyzed for cholesterol, total protein, albumin, globulin and urea. The serum biochemical indices were done using the clinical routine procedures outlined by Olorede et al. (1996)

\subsection{Statistics and Data analysis}

The data collected were statistically analyzed by analysis of variance using Repeated Measures in General Linear Model in the statistical package SPSS (2009) using the following statistical model:

$$
\mathrm{X}_{\mathrm{ij}}=\mu+\mathrm{H}_{\mathrm{i}}+\mathrm{E}_{\mathrm{ij}}
$$

Where,

$\mathrm{X}_{\mathrm{ij}}=$ any observation made in the experiment; $\mu$ = the population mean; $\mathrm{H}_{\mathrm{i}}=$ effect of type of herb ( $\mathrm{I}=$ ginger, garlic); $\mathrm{E}_{\mathrm{ij}}=$ residual error.

\section{Results and Discussion}

\subsection{Growth Performance}

The summary of the effect of the different herbs on growth performance traits of broiler chickens is presented in Table 1. There were significant differences $(\mathrm{P}<0.05)$ between treatments in performance traits. Birds on ginger infusion had a better performance for all traits studied, there was a 29.07, 16.60 and $14.98 \%$ significant $(\mathrm{P}<0.05)$ increase in final body weight relative to T1, T3 and T4 respectively. The present findings affirm the work of Herawati (2010) on Hubbard broiler strains. The authors observed a significant increase in final body weight, higher feed intake and better feed conversion ratio of birds fed $2 \%$ supplemented red ginger in their diet). Similar result was obtained by Al-Moramadhi (2010) when broiler chicks were given ginger orally at $100 \mathrm{mg} / \mathrm{kg}$ body weight for six weeks. Minh et al. (2010) and Onu (2010) also reported that supplementation of dried ginger to broiler diets resulted in improved performance. Ademola et al. (2009) also observed that ginger increased body weight when included in the diet up to $2 \%$ level in the diet. The better performance observed in T2 could be attributed to some medicinal properties contained in ginger. For instance, a protein digesting enzyme (zingibain) found in ginger is believed to improve digestion as well as kill parasites and their eggs. Furthermore, properties in ginger tends to enhance antibacterial and anti inflammatory factors (Mohammed \& Yusuf, 2011). Tekeli (2007) stated that due to the active ingredients in these herbs, there is the formation of more stable intestinal flora and improved feed conversion efficiency in consequence of a better digestion.

Table 1. Growth performance of broiler chicks given aqueous infusion of ginger and garlic

\begin{tabular}{lllllll}
\hline Parameters & $\mathrm{T} 1$ & $\mathrm{~T} 2$ & $\mathrm{~T} 3$ & $\mathrm{~T} 4$ & SEM & P-Value \\
& $0 \mathrm{ml}$ & $50 \mathrm{ml}$ ginger & $50 \mathrm{ml}$ galic & $50 \mathrm{ml}$ ginger \& garlic & & \\
\hline Final body weight $(\mathrm{g})$ & $1930.80^{\mathrm{c}}$ & $2684.40^{\mathrm{a}}$ & $2238.20^{\mathrm{b}}$ & $2282.20^{\mathrm{b}}$ & 24.07 & 0.00 \\
Weekly weight gain $(\mathrm{g})$ & $274.99^{\mathrm{c}}$ & $383.49^{\mathrm{a}}$ & $319.74^{\mathrm{b}}$ & $326.03^{\mathrm{b}}$ & 3.41 & 0.00 \\
Weekly feed intake $(\mathrm{g})$ & $538.73^{\mathrm{b}}$ & $567.08^{\mathrm{a}}$ & $535.30^{\mathrm{b}}$ & $534.48^{\mathrm{b}}$ & 4.19 & 0.00 \\
Feed Conversion Ratio & $1.96^{\mathrm{a}}$ & $1.48^{\mathrm{c}}$ & $1.67^{\mathrm{b}}$ & $1.64^{\mathrm{b}}$ & 0.125 & 0.00 \\
\hline
\end{tabular}

Note. ${ }^{a b c}$ Means on the same row followed by different superscripts are significantly different $(\mathrm{p}<0.05) ;$ SEM Standard Error of Mean.

Though in the present study, birds on T2 performed better than those on T3 and T4, these two treatments were 
significantly $(\mathrm{p}<0.05)$ better than the control. Mahmood et al. (2009) reported that garlic had positive effect on the growth rate of broiler chicks. Meraj (1998) noted that the presence of antibiotic substances in garlic is responsible for the improvement of weight gain. In consonance, Rehman et al. (2012) reported that mean feed conversion ratio was significantly influenced by water based infusion of garlic and Withania somnifera. The reports of Ashayerizadeh et al. (2009) and Mohebbifar and Torki (2011) showed that inclusion of garlic powder in broiler feed did not change body weight, feed intake and efficiency/feed conversion ratio. Lawson et al. (1992) observed that allicin is unstable and poorly absorbed from the digestive tract. Present findings also support the findings of Javed et al. (2009) which showed a positive effect of aqueous extract of plant mixture (Zingiber officinale, Carum apticum, Withania somnifera, Trigonella Foenum-Graecum, Silybum marianum, Allium sativum and Berberis lyceum) on the performance of broiler chicks in term of weight gain and Feed Conversion Ratio.

\subsection{Haematological and Serum Biochemical Assay}

The results of the haematological and serum biochemical response of broiler chickens administered aqueous extract of test ingredients are presented in Table 2 .

Table 2. Haematological and serum biochemical response of broiler chickens administered aqueous extract of test ingredients

\begin{tabular}{lllllll}
\hline \multirow{2}{*}{ Parameters } & $\mathrm{T} 1$ & $\mathrm{~T} 2$ & $\mathrm{~T} 3$ & $\mathrm{~T} 4$ & \multirow{2}{*}{$\mathrm{m}$} & \multirow{2}{*}{ P-Value } \\
& $0 \mathrm{ml}$ & $50 \mathrm{ml}$ ginger & $50 \mathrm{ml}$ galic & $50 \mathrm{ml}$ ginger \& garlic & & \\
\hline PCV $(\%)$ & $24.89^{\mathrm{b}}$ & $28.22^{\mathrm{ab}}$ & $29.14^{\mathrm{a}}$ & $25.5^{\mathrm{b}}$ & 1.96 & 0.010 \\
$\mathrm{HB}(\mathrm{g} / \mathrm{dl})$ & $8.00^{\mathrm{b}}$ & $9.30^{\mathrm{a}}$ & $9.73^{\mathrm{a}}$ & $8.38^{\mathrm{b}}$ & 0.38 & 0.001 \\
$\mathrm{RBC}\left(10^{12} / \mathrm{mm}^{3}\right)$ & $2.15^{\mathrm{c}}$ & $2.62^{\mathrm{ab}}$ & $2.80^{\mathrm{a}}$ & $2.46^{\mathrm{b}}$ & 0.16 & 0.001 \\
$\mathrm{WBC}\left(10^{9} / \mathrm{mm}^{3}\right)$ & $6.30^{\mathrm{c}}$ & $7.10^{\mathrm{ab}}$ & $7.49^{\mathrm{a}}$ & $6.80^{\mathrm{b}}$ & 0.22 & 0.001 \\
Platelets & 166.00 & 140.00 & 150.00 & 170.00 & 15.42 & 0.173 \\
Cholesterol(mg/dl) & $245.43^{\mathrm{a}}$ & $225.77^{\mathrm{a}}$ & $200.00^{\mathrm{b}}$ & $230.37^{\mathrm{a}}$ & 14.59 & 0.048 \\
Protein $(\mathrm{g} / \mathrm{l})$ & $4.50^{\mathrm{c}}$ & $5.85^{\mathrm{b}}$ & $6.54^{\mathrm{a}}$ & $5.38^{\mathrm{b}}$ & 0.29 & 0.000 \\
Albumin $(\mathrm{g} / \mathrm{l})$ & $2.56^{\mathrm{c}}$ & $3.44^{\mathrm{b}}$ & $4.02^{\mathrm{a}}$ & $3.32^{\mathrm{b}}$ & 0.27 & 0.000 \\
Globulin(mg/dl) & $1.78^{\mathrm{c}}$ & $2.40^{\mathrm{a}}$ & $2.53^{\mathrm{a}}$ & $2.04^{\mathrm{b}}$ & 0.18 & 0.004 \\
Urea $(\mathrm{mg} / \mathrm{dl})$ & 42.00 & 40.00 & 40.36 & 41.10 & 1.67 & 0.503 \\
\hline
\end{tabular}

Note. ${ }^{\text {abc }}$ Means on the same row followed by different superscripts are significantly different $(\mathrm{p}<0.05)$; SEM Standard Error of Mean.

There was significant increase $(\mathrm{P}<0.05)$ in the $\mathrm{PCV}, \mathrm{Hb}, \mathrm{RBC}$, and $\mathrm{WBC}$ of birds on the ginger and garlic infusion than those on control treatment. Mitruka et al. (1977) stated that the number of erythrocytes (RBC) in chicken is influenced by the conditions of the animal. The increase in PCV, $\mathrm{Hb}$, and RBC contents of the blood of birds fed the test ingredients is an indication of improved oxygen carrying capacity of the cells which translated to a better availability of nutrients to the birds consequently affecting their well-being. Sole administration of ginger and garlic numerical reduced the platelets in the blood. Muhammed and Lakshmi (2007) opined that inhibiting the transformation of arachidonic acid to thromboxane and decreasing the sensitivity of platelets to aggregating agents may be possible with the administration of ginger in fatty diets. This implies that ginger could be potentially useful in improving blood circulation on account of its inhibitory effects on platelet aggregation (Muhammed \& Lakshmi, 2007). Similar inhibitory effect was observed in garlic by Lawson et al. (1992).

The result on serum biochemical indices indicates that inclusion of ginger and garlic in the water of broiler chickens successfully reduced the cholesterol in the serum. The present findings also reveal that the ginger extract caused reduction in the levels of serum cholesterol, though the mixture of the two (ginger and garlic) did not show any variation from the control where the cholesterol statistically increased. Saeid et al. (2010) observed that aqeous extract of ginger significantly reduced the level of cholesterol in the blood of broilers. Bhandari et al. (1998) and Akhani et al. (2004) also reported that ginger treatment significantly decreased serum cholesterol. This affirms the findings of Mansoub (2011) who reported reductions in total cholesterol when broilers were 
supplemented with $1 \mathrm{~g} / \mathrm{kg}$ garlic. The results of present study is, also, in agreement with Stanacev et al. (2011) who reported that garlic manifested hypocholesterolemic effects on chickens through inhibition of the most important enzymes that participate in the synthesis of cholesterol and lipids. Konjufca et al. (1997) reported that garlic reduced plasma cholesterol by decreasing the activity of 3-hydroxy-3-methlyglutaryl reductase. Allicin has been proposed as the active compound in garlic responsible for health promotion and hypocholesterolaemic benefits (Lawson, 1998). The result of the present study affirms the findings of Al-Moramadhi (2010) on the effect of ginger root infusion on haematological parameters in broiler chickens. The reduction in cholesterol level can be traced to the presence of gingerols and shagols components in ginger which inhibits lipid peroxidation (Verma et al., 2004; Ashani \& Verma, 2009).

\section{Conclusion}

A mixture of the two herbs was not as beneficial as sole treatment (treatment either with ginger or garlic) in all parameters studied. Although, birds on aqueous extract of ginger, had better performance in terms of final body weight and feed conversion ratio, administration of aqueous extract of garlic in the broilers drinking water improved the haematological and serum parameters studied. The result of the present study, therefore, suggests that the use of ginger and garlic as aqueous extract in the diets of broiler chickens improved their performance as well as their health status. Generally, administration of aqueous extract of ginger and garlic is recommended in broiler production for improved nutritional and physiological traits in broiler chickens.

\section{References}

Ademola, S. G., Farinu, G. O., \& Babatunde, G. M. (2009). Serum lipid growth and hematological parameters of broilers fed garlic, ginger and their mixtures. World Journal of Agricultural Science, 5(1), 9-104.

Adibmoradi, M., Navidshad, B., Seifdavati, J., \& Royan, M. (2006). Effect of dietary garlic meal on histological structure of small intestine in broiler chickens. Journal of Poultry Sciences, 43, 378-383. http://dx.doi.org/10.2141/jpsa.43.378

Aji, S. B., Ignatuius, K., Ado, A. Y., Nuhu, J. B., \& Abdulkarim, A. (2011). Effect of feeding onion (Allium cepa) and garlic (Allium sativum) on some performance characteristics of broiler chickens. Research Journal of Poultry Science, 4, 22-27. http://dx.doi.org/10.3923/rjpscience.2011.22.27

Akhani, S. P., Vishwakarma, S. L., \& Goyal, R. K. (2004). Anti-diabetic activity of Zingiber officinale in Streptozotocin-induced type I diabetic rats. J. Pharmacy Pharmacol., 56, 101-105. http://dx.doi.org/10.1211/0022357022403

Al-Amin, Z. M., Thomson, M., Al-Qattan, K. K., Peltonen-Shalaby, R., \& Ali, M. (2006). Anti-diabetic and hypolipideamic properties of ginger (Zingiber officinale) in streptozotocin-induced diabetic rats. Br. Journ. Nutr., 96, 660-666. http://dx.doi.org/10.1079/BJN20061849

Ali, B. H., Blunden, G., Tanira, M. O., \& Nemmar, A. (2008). Some phytochemical, pharmacological and toxicological properties if ginger (Zingiber officinale Roscoe): A review of recent research. Food Chemistry and Toxicology, 46, 409-420. http://dx.doi.org/10.1016/j.fct.2007.09.085

Al-Moramadhi, S. A. H. (2010). The effect of Zingiber officinali roots infusion on some physiological parameters in broiler chickens. Kufa Journal for Veterinary Medical Sciences, 1(2), 67-76.

Ashani, V. M., \& Verma, R. J. (2009). Ameliorative effects of ginger extract on paraben-induced lipid peroxidation in the liver of mice. Acta Pol Pharm., 66(3), 225-228.

Ashayerizadeh, O., Daster, B., \& Shargh, M. S. (2009). Use of garlic (Allium sativum), black cumin seeds and wild mint (Mentha longifolia) in broiler chicken diets. Journal of Animal and Veterinary Advance, 8, 1860-1863.

Ayaşan, T. (2011). Black Cumin and Usage of Poultry Nutrition. National Poultry Congressi 14-16 September 2011 (pp. 1228-1236). University of Cukurova, Agricultural of Faculty, Animal Science Division, Adana, Turkey.

Bhandari, U., \& Grover, J. K. (1998). Effect of ethanolic extract of ginger on hyperglycemic rats. Int. J. Diabetes, 6, 95-96.

Chang, K. J., \& Cheong, S. H. (2008). Volatile organosulfur and nutrient compounds from garlic by cultivating areas and processing methods. Fed. Am. Soc. Exp. Bio. J., 22, 1108.2.

Elagib, H. A. A., \& Ahmed, A. D. A. (2011). Comparative study on haematological values of blood of indigenous chickens in Sudan. Asian Journal of Poultry Science, 5(1), 41-45. 
http://dx.doi.org/10.3923/ajpsaj.2011.41.45

Gardzielewska, J., Pudyszak, K., Majewska, T., Jakubowska, M., \& Promianowski, J. (2003). Effect of plantsupplemented feeding on fresh and frozen storage quality of broiler chicken meat. Animal Husbandry Series of Electronic J. Polish Agric-Univ., $6(2)$. Retrieved from http://www.ejpau-media.pl/series/volumes/issues/animal/art-12.html

Gbenga, O. E., Adebisi, O. E., Fajemisin, A. N., \& Adetunji, A. V. (2009). Response of broiler chickens in terms of performance and meat quality to garlic Allium sativum supplementation. African Journal of Agric. Res., 4, 511-517.

Guo, F. C. (2003). Mushroom and herb polysaccharides as alternative for antimicrobial growth promoters in poultry (Unpublised doctoral dissertation). Wageningen University, Netherlands.

Hanieh, H., Narabara, K., Piao, M., Gerile, C., Abe, A., \& Kondo, Y. (2010). Modulatory effects of two levels of dietary alliums on immune response and certain immunological variables, following immunization, in white leghorn chicken. Animal Science Journal, 873-680. http://dx.doi.org/10.1111/j.1740-0929.2010.00798.x

Herawati, O. (2010). The effect of red ginger as phytobiotic on body weight gain, feed conversion and internal organs condition of broiler. Int. J. Poult. Sci., 9(10), 963-967. http://dx.doi.org/10.3923/ijps.2010.963.967

Javed, M., Durrani, F., Hafeez, A., Khan, R. U., \& Ahmad, I. (2009). Effect of aqueous extract of plant mixture on carcass quality of broiler chicks. ARPN JABS, 4(1), 37-40.

Konjufca, V. H., Pesti, G. M., \& Bakalli, R. I. (1997). Modulation of cholesterol levels in broiler meat by dietary garlic and copper. Poultry Science, 76, 1264-1271. http://dx.doi.org/10.1093/ps/76.9.1264

Lamb, G. N. (1991). Manual of veterinary laboratory technique (pp. 98-99). CIBA-GEIGY, Kenya.

Lawson, L. D. (1998). Garlic: A review of its medicinal effects and indicated active compounds. In L. D. Lawson \& R. Bauer (Eds.), Phytomedicines of Europe: chemistry and biological activity (Vol. 91, pp. 176-209). Washington, ACS symposium Series, USA.

Lawson, L. D., Ransom, D. K., \& Hughes, B. G. (1992). Inhibition of whole blood platelet-aggregation by compounds in garlic clove extracts and commercial garlic products. Thromb. Res., 65, 141-156. http://dx.doi.org/10.1016/0049-3848(92)90234-2

Leila, S. M. (1977). A manual on some Philippine medicinal plants (preparation of drug materials). Bot. Soc., U.P., 20, 78-82.

Madubuike, F. N., \& Ekeyem, B. U. (2001). Non ruminant Livestock Production in the Tropics (p. 185). Gust-chuks Grapics, Owerri, Nigeria.

Mahmood, S., Hassan, M. M., Alam, M., \&Ahmad, F. (2006). Comparative efficacy of Nigella sativa and Allium sativum as growth promoters in broilers. Inter. Jour. of Agric. and Biol., 11, 775-778.

Manseh, M. K., Kazemi, S., \& Asfari, M. (2012). Influence of poly germander (trucrium polium) and watercress (Nasturtium officinale) extract on performance, carcass quality and blood metabolites of males broilers. Research Options in Animal \& Veterinary Sciences, 2, 66-68.

Mansoub, N. H. (2011). Comparative effects of using garlic as probiotic on performance and serum composition of broiler chickens. Annals of biological Research, 2, 486-490.

Meraj, I. C. A. (1998). Effect of garlic and neem leaves supplementation on the performance of broiler chickens. M. Sc. Thesis, Department of Poultry Science, University of Agriculture, Faisalabad, Pakistan.

Minh, D. V., Huyen, L. V., Theun, P., Tuan, T. Q., Nga, N. T., \& Khiem, N. Q. (2010). Effect of supplementation of ginger (Zingiber officinale) and garlic (Allium sativum) extracts (phyto- antibiotics on digestibility and performance of broiler chicken. MFKARN conference on livestock production, climate change and resource depletion. Retrieved from http://www.mekarn.org/workshops/pakse/abstracts/minh_nias.htm

Mitruka, B. M., Rawnsley, H. M., \& Vadehra, B. V. (1977). Clinical biochemical and haematological reference values in normal experimental animals. Masson Publishing USA Inc. 272.

Mohammed, A. A., \& Yusuf, M. (2011). Evaluation of ginger (Zingiber officinale) as a feed additive in broiler diets. LRRD, 23(9), Article \# 202. Retrieved from http://www.lrrd.org/lrrd23/9/moha23202.htm

Mohebbifar, A., \& Torki, M. (2011). Growth performance and humoral response of broiler chicks fed diet containing graded levels of ground date pits with a mixture of dried garlic and thyme. Global Veterinaria, 6, 
389-398.

Muhammed, M., \& Lakshmi, P. (2007). Ginger (Zingibe officinale): Product Write-Up. Retrieved from http://www.sabinsa.com/products/standardized-phytoextracts/ginger/ginger.pdf

Nwakpu, C. (2005). Practical guide to lowland rice production in Nigeria. SNAAP Press Ltd. Enugu.

Ogle, M. (2013). Riots, Rage, Resistance: A Brief History of How Antibiotics Arrived on the Farm. Scientific American. Retrieved November 5, 2014.

Olorede, B. R., Onifade, A. A., Okpara, A. O., \& Banatunde, G. M. (1996). Growth, nutrient retention, haematoology and serum chemistry of broiler chickens fed sheabutter cake or palm kernel cake in the humid tropics. J. of Applied Animal Research, 10, 173-180. http://dx.doi.org/10.1080/09712119.1996.9706146

Onu, P. N. (2010). Evaluation of two herbal spices as feed additives for finisher broilers. Biotechnology in Animal Husbandry, 26, 383-392. http://dx.doi.org/10.2298/BAH1006383O

Rehman, Z. U., Khan, S., Chand, N., Tanweer, A. J., Sultan, A., Akhtar, A., \& Tauqeer, A. M. (2012). Effect of water based mixture infusion of allium sativum and withania somnifera on performance of broiler chicks. Pakistan Journal of Science, 64(3), 180-183.

Rivlin, R. S. (2001). Historical perspective on the use of garlic. J. Nutr., 131(35), 957-954.

Saeid, J. M., Mohamed, A. B., \& AL-Baddy, M. A. (2010). Effect of aqueous extract of ginger (zingiber officinale) on blood biochemistry parameters of broiler. Int. J. Poult. Sci., 9(10), 944-947. http://dx.doi.org/10.3923/ijps.2010.944.947

SPSS. (2009). Computer software SPSS Inc. Headquarters, Wacker Drive, Chicago, Illinois-U.S.A.

Stanacev, V., Glamoci, D., Miloševic, N., Puvacac, N., Stanacev, V., \& Plavša N. (2011). Effect of garlic (allium sativum l.) in fattening chicks Nutrition. African Journal of Agricultural Research, 6(4), 943-948.

Tapsell, L. C., Hemphill, I., Cobiac, L., Patch, C. S., Sullivan, D. R., Fenech, M., ... Inge, K. E. (2006). Health benefits of herbs and spices: The past, the present, the future. Med. J. Aust., 185, 4-24. http://dx.doi.org/10.3923/crpsaj.2011.12.23

Tekeli, A., Kutlu, H. R., \& Celik, L. (2011). Effect of Z. officinale and propolis extracts on the performance, carcass and some blood parameters of broiler chicks. Current Research in Poultry Science, 1(1), 12-23.

Verma, S. K., Singh, M., Jain, P., \& Bordia, S. (2004). Protective effect of ginger, (Zingiber officinale Rosc), on experimental atherosclerosis in rabbits. Indian J. Exp. Biol., 42, 736-738.

Wegener, H. C., Aarestrup, F. M., Benner-Smidt, P., \& Bager, F. (1999). Transfer of antibiotic resistant bacteria from animal to man. Acta. Vet. Scand. Suppl., 92, 51-57.

Zhao, X., Yang, Z. B., Yang, W. R., Wang, Y., Jiang, S. Z., \& Zhang, G. G. (2011). Effects of ginger roots (Zingiber officinale) on laying performance and antioxidant status of laying hens and on dietary oxidation stability. Poultry Science, 90, 1720-1727. http://dx.doi.org/10.3382/ps.2010-01280

\section{Copyrights}

Copyright for this article is retained by the author(s), with first publication rights granted to the journal.

This is an open-access article distributed under the terms and conditions of the Creative Commons Attribution license (http://creativecommons.org/licenses/by/3.0/). 